\title{
Significant directions of digitalization of the Khabarovsk Territory economy in the implementation of the national program "Digital Economy"
}

\author{
Luyciena Piunko, Elena Tolkacheva \\ Department of Mathematical Methods and Information Technologies, Far-East Institute of \\ management, branch of the Russian Presidential Academy of National Economy and Public \\ Administration (hereinafter RANEPA), 680000 Khabarovsk, Russia
}

\begin{abstract}
The research is devoted to the modern development of digital transformation in the Russian economy, including in the Khabarovsk Territory; the difficulties of implementing the directions of the "Digital Economy". In this study, an attempt is made to compare the strategic goals of the development of the "Digital Economy", modern processes of digital transformation and such an important component of it as "Integration 4.0" related to the "industrial Internet", digital production, intelligent components, including the collection of large amounts of data, cyberphysical systems, remote monitoring and maintenance. "Industry 4.0" accelerates production processes, increases its efficiency and the quality of manufactured goods, reduces the cost of delivery, tracks production chains, etc. Currently, the industry of Western countries uses Industry 4.0 standards at the production management level. In developed countries, such as Germany, South Korea, etc., they realize the importance of automation and computerization, which became the main tool of the third industrial revolution, and its tools for the transition to "Industry 4.0". International standards are developed for industries that use computer algorithms to monitor and control physical things, such as equipment, robots and vehicles. Standards that work on the basis of the Industrial Internet of Things (IIoT) and cyber - physical systems - intelligent autonomous systems that define all components of the supply chain, transforming production processes into "smart" - from smart manufacturing and factories to smart warehouses and logistics. And, the same systems are associated with the previous stage of industrial production, such as enterprise resource planning (ERP). All this ensures a high level of transparency and control over the activities of the organization. At the present stage, there are excellent opportunities for the development of Industry 4.0 in Russia, but there are also difficulties, overcoming which are significant directions of the digitalization processes of the modern economy. The authors devoted their research to the analysis of such difficulties.
\end{abstract}




\section{Introduction}

The modern socio-economic development of Russia is being modernized through the implementation of major national programs, one of which is the "Digital Economy". At the same time, the main task of digitalization of the economy is to minimally reduce intermediaries in the chain from the producer of goods (products) to the end consumer, i.e., to reduce the number of such intermediaries close to zero and thereby reduce the cost of goods or services. The digital economy, its goals and objectives are built around transactions in which intermediaries should be replaced by information and communication technologies, digital technologies, etc.

The main goals and objectives to ensure the convenience of concluding transactions between consumers (individuals or legal entities) and manufacturers (sellers) are being implemented in Russia today, i.e., such areas as "Information Infrastructure", "Artificial Intelligence", "Digital public administration" are successfully developing and improving, taking into account new challenges. At the same time, there are areas of digital transformation that are not so successful, for example, "Information Security", "Industrial Internet", "Industry 4.0", "Personnel for the digital economy".

At the same time, the existing dynamics of the modern market forces manufacturers to fight for their consumers, including through the introduction of high-tech tools into the processes of interaction with consumers. The digital solutions currently being created that allow manufacturers to remain competitive in the market should take into account the processes of penetration of goods and services into consumer markets and the formation of awareness about new products.

In the conditions of digitalization of the Khabarovsk Region economy, the main problem is the processes of introducing high-tech digital means of interaction between producers and consumers of goods and services. It should be noted that the Khabarovsk Territory is very far from the western regions of Russia, with a weakened human resource potential in many areas of the economy. Khabarovsk Region is much inferior to many Russian regions in terms of the intensity of digitalization of the economy. At the same time, there is a potential for the introduction and development of "Industry 4.0" for large manufacturing enterprises in the region.

\subsection{The study of aspects of the development of "Industry 4.0" in the scientific community}

The problems of interaction between producers and consumers in the conditions of digitalization were considered by a number of domestic and foreign scientists.

So, Kim D, Hwong A, Stafford D, Hughes A O'Malley J, Fowler J. [1], considered the issues of studying the features of the digital environment as a source of information for consumers. Piccinini E., Gregory R.W., Kolbe L. proposed an analysis of fundamental changes in the relationship between producers and consumers due to the wider use of digital technologies. [2] Moreover, their research has already created a request for the importance of information transparency management in order to selectively disclose information to consumers, suppliers and competitors through digital channels. At the same time, the authors do not explain in their publications what they mean by "selective disclosure of information".

Krasyuk I.A., Kolgan M.V. the main conditions and criteria for the implementation of integration in the chain of interaction between the producer and the consumer, taking into account digital changes, were identified and structured. [3]

Vatlina L.V., Moroz O.N. noted that manufacturers need to take into account their requests and interests when implementing interaction with users. Accordingly, 
manufacturers need to maintain a balance between digital and traditional shopping formats, master new sales channels through mobile services of online stores and improve the digital competencies of staff. [4]

Radygina E.G., notes that the algorithms of interaction between the manufacturer and the consumer are becoming more and more information-rich and high-tech, which entails the elimination of time and spatial constraints. [5]

Features of state regulation of digital trade are considered by Sergeev I.V. [6].

\section{Analysis of regional policy on the development of "industry 4.0" and digital transformation of production}

In our understanding, based on the analysis of domestic and foreign researchers of "Industry 4.0" and related digital transformations, transparency of information about goods (products), including the chains of interaction between producer and consumer, taking into account digital changes, should be equally accessible to all participants of digital interaction. In other words, so that "selective disclosure of information" does not create a basis of discrimination for individual sellers or for individual buyers; keeping the competitive environment healthy.

In general, it should be noted that digitalization is considered in research as a source of information for consumers. At the same time, the issues of state regulation of the development of digital interaction between producers of goods and services and consumers, especially in the regional aspect, are not sufficiently disclosed. At the same time, the actual transition of the market to the digital economy has changed the implementation of all key operations of the process of interaction between the producer and the consumer.

Thus, in this study, we characterize the problems of implementing regional policy in the implementation of the regional national project "Digital Economy" in the Khabarovsk Territory, a comparative analysis of the main indicators of the production of electronic equipment in Russia and the Khabarovsk Region as a significant condition for the development of digital interaction between manufacturers and consumers.

If we consider the official statistics for 2020 - 2021 for manufacturing industries, the index of electronic equipment production in August 2021 compared to the corresponding period of the previous year was $98.6 \%$, in January-August $2021-107.9 \%$, which generally reflects the positive dynamics of the production of certain types of computers, electronic and optical products in Russia. [7, 10].

Table 1. Indices for the production of certain types of technological products in Russia in the period 2020 - 2021 [7].

\begin{tabular}{|c|c|c|c|}
\hline \multirow{2}{*}{ Indices and output volume } & \multicolumn{2}{|c|}{ August 2021 in \% to } & $\begin{array}{c}\text { January-August } \\
\mathbf{2 0 2 1} \text { in \% to } \\
\text { January-August } \\
\mathbf{2 0 2 0}\end{array}$ \\
\cline { 2 - 4 } & $\begin{array}{c}\text { August } \\
\mathbf{2 0 2 0}\end{array}$ & July 2021 & 102.3 \\
\hline $\begin{array}{c}\text { Manufacture of computers, electronic and } \\
\text { optical products }\end{array}$ & 75.2 & 101.8 & 107.9 \\
\hline Manufacture of electrical equipment & 98.6 & 97.2 & \\
\hline
\end{tabular}


Continuation of table 1.

\begin{tabular}{|c|c|c|c|}
$\begin{array}{c}\text { Vacuum or gas-filled electronic lamps and } \\
\text { tubes with thermocathode, cold cathode, } \\
\text { photocathode, including cathode ray tubes, } \\
\text { billion rubles }\end{array}$ & 127.3 & 103.6 & 149.4 \\
\hline $\begin{array}{c}\text { Printed circuit boards mounted, million } \\
\text { pieces }\end{array}$ & 122.3 & 105.0 & 126.8 \\
\hline $\begin{array}{c}\text { Radar, radio navigation and remote-control } \\
\text { equipment, billion rubles }\end{array}$ & 113.9 & 104.6 & 126.5 \\
\hline $\begin{array}{c}\text { Computers, their parts and accessories, } \\
\text { billion rubles }\end{array}$ & 74.9 & 86.5 & 90.9 \\
\hline $\begin{array}{c}\text { Television receivers, combined or not } \\
\text { combined with a broadcast radio receiver or } \\
\text { equipment for recording or reproducing } \\
\text { sound or image, thousand pieces }\end{array}$ & 66.3 & 159.8 & 91.7 \\
\hline $\begin{array}{c}\text { Gas production or consumption meters, } \\
\text { thousand pieces }\end{array}$ & 112.4 & 87.8 & 125.6 \\
\hline
\end{tabular}

\subsection{The level of digitization in the region}

The data presented in Table 1 reflect an increase in the production of electronic products, radar equipment, mounted printed circuit boards, gas production or consumption meters; at the same time, a decrease in the production of computer equipment. But it is computers and other digital equipment that are necessary for Russia's transition to "Industry 4.0"; including taking into account the low level of digitization and insufficient costs of enterprises for innovative renewal of production in the country today, the pace of transition to a new technological way of production is slow. This circumstance further increases the gap in terms of the transition to "Industry 4.0" for Russia in comparison with Germany, South Korea, etc

Given that in the Khabarovsk Region the level of digitization is lower than the allRussian one (it is also associated with the northern territories of the region, which are poorly populated, Fig. 1), it is necessary to launch enterprises for the production of electrical and certain types of digital equipment, train personnel for the development of this economic sector.

The share of products of high-tech and knowledge-intensive industries in the gross product of the Khabarovsk Territory is decreasing (in any case, it is not increasing), which raises serious concerns about the near-term implementation of "Industry 4.0" in the Khabarovsk Region.

Regarding the Khabarovsk Territory in the field of high-tech industries, the share of high-tech and knowledge-intensive industries in the gross regional product is presented in Table 2. [8, 11]. 
Table 2. The share of high-tech and knowledge-intensive industries in the gross product of the Khabarovsk Territory.

\begin{tabular}{|l|c|c|c|c|}
\hline Khabarovsk Territory & $\mathbf{2 0 1 6}$ & $\mathbf{2 0 1 7}$ & $\mathbf{2 0 1 8}$ & $\mathbf{2 0 1 9}$ \\
\cline { 2 - 5 } & 16.7 & 17.0 & 17.8 & 16.9 \\
\hline
\end{tabular}

Currently, the Ministry of Industry and Trade of Russia and Rosstandart have updated the Long-term Standardization Plan in the field of advanced production technologies for 2018 - 2025, proposed by the working group on improving legislation and removing administrative barriers of NTI Technet together with the technical committee "Cyberphysical Systems", created on the basis of RVC $[9,12]$.

The document provides for the development of over 120 regulatory and technical documents regulating end-to-end technologies of the modern digital industry. In addition to the traditional areas - the Internet of Things, industrial Internet of Things, big data, artificial intelligence, smart manufacturing, cyber-physical systems - the plan is supplemented with new directions, including standards in the field of augmented reality, as well as electronic design and operational documentation. The development of the standards provided for in the plan is aimed at increasing the competitiveness of Russian companies and products by accelerating the introduction of advanced manufacturing technologies in Russia. [9, 13]

The German research Center for Artificial Intelligence suggests that cyber-physical systems are at the heart of the fourth industrial revolution.

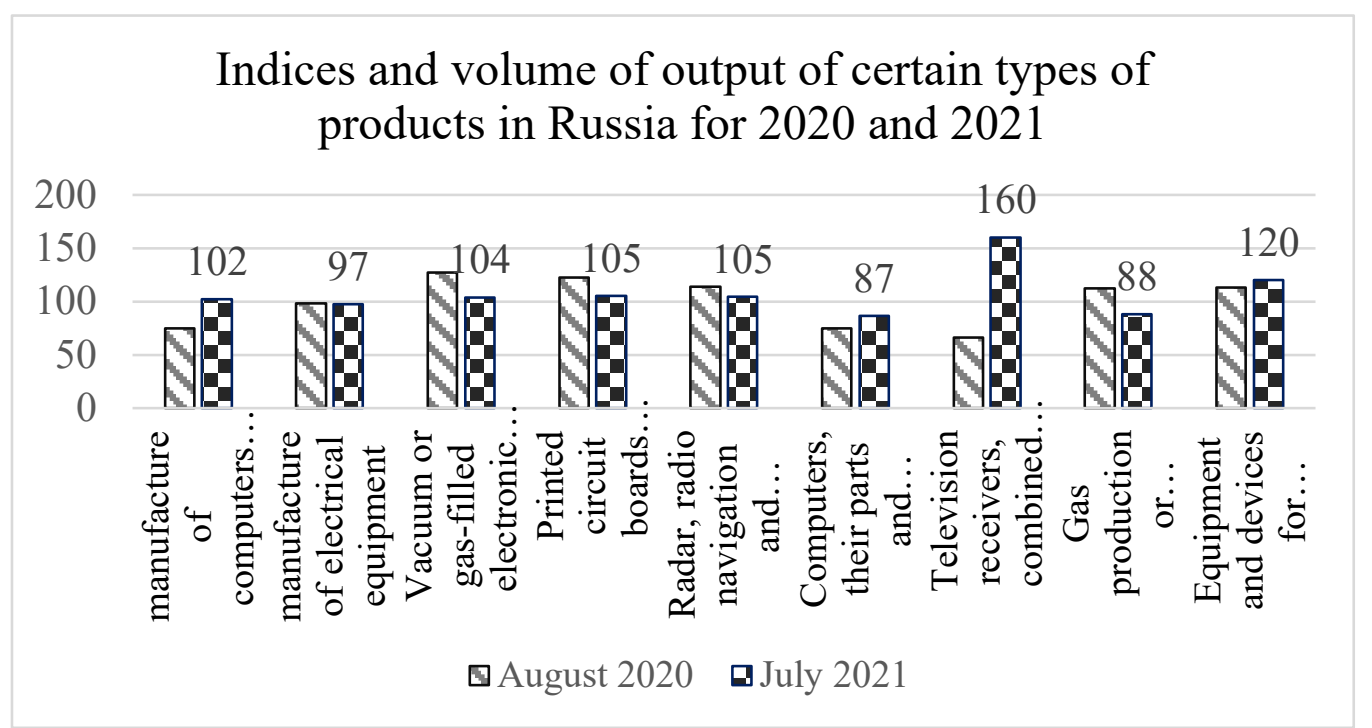

Fig. 1. Indices for the production of certain types of products in Russia in the period 20202021.

* The diagram is compiled by the authors on the basis of statistical data.

\subsection{Modern development of technologies in industry}

The evolution of technologies in industry, implying that traditional production processes are integrated with information and communication technologies (ICT/ IoT) and information systems of the manufacturer and represents the "Industry 4.0". Currently in China, Germany, South Korea, etc. with the development of microelectronics, programming technologies, information and communication technologies, the use and 
production of collaborative robotics and control technologies for large groups of unmanned vehicles moving on land, air and water are actively developing.

In Russia, an analogue of collaborative robotics has been used for a relatively long time in nuclear reactors: control and measuring equipment. At the same time, the use of collaborative robotics is now being integrated into production cycles at Russian production facilities and this area is receiving close attention from developers.

\section{Conclusion}

1. At the moment, the Russian industry is potentially ready and is implementing a transition from discussing the concepts of "Industry 4.0" to practical project programs. Perhaps, given the external risks, not all information on the development of Industry 4.0 in Russia is publicly available, which is related to information security, as well as economic and national security.

2. "Niche" IT companies continue to appear in Russia, offering promising solutions in applied areas and clusters of "Industry 4.0" technologies: artificial intelligence, the Internet of Things, industrial robotics.

3. Such areas as "Industrial Internet" and "Industry 4.0" are not directly stated in the federal project "Digital Technologies", but are designated by the creation and development of endto-end digital technologies based on domestic developments, the development of high-tech products and services, import substitution in quantum technologies, 5G and other areas. These developments are partially implemented by state corporations (Roscosmos, Rostechnologies, Rosatom, etc.).

4. The main international technical concepts for "Industry 4.0" imply the use of digital twins by manufacturers, processing of industrial data (analogous to Big Data for the industrial sector), integration of architectures for corporate systems.

5. It is necessary to develop analogues of the Western concepts of the "Smart Production System Committee" and "System architecture of digital representation of physical objects in production environments", taking into account the peculiarities of the Russian socioeconomic space. For the Khabarovsk Region, the introduction of the concept of "Smart Production" is currently being considered for large enterprises in the region.

6. In Russia, official documents regulating the development programs of "Industry 4.0" are only at the development stage. At the same time, the measures being developed as part of the implementation of the federal Information Infrastructure project are important for the development of Industry 4.0 in Russia, including in the Khabarovsk Territory.

7. Thus, further implementation of measures to create a high-speed data transmission infrastructure accessible to all economic entities of the Khabarovsk Region and its residents. This, in turn, will allow building digital interaction between manufacturers and users, taking into account the needs of the latter in high-quality goods and services, including in remote areas of the region.

8. At the same time, the share of high-tech and knowledge-intensive industries in the gross regional product in the Khabarovsk Territory is insufficiently represented and has a downward trend. It is necessary to develop public administration measures to correct this negative trend. Because the prerequisites for the development of "Industry 4.0 " in the Khabarovsk Region at the present time.

\section{Acknowledgment}

This work was supported by Far-East Institute of management, branch of the Russian Presidential Academy of National Economy and Public Administration (hereinafter 
RANEPA), Department of mathematical methods and information technologies, Khabarovsk 680000, Russia.

\section{References}

1. D. Kim, A. Hwong, D. Stafford, A. Hughes, J. O'Malley, J. Fowler, Social network targeting to maximise population behaviour change: a cluster randomised controlled trial, The Lanclet, 386, 145-153 (2015)

2. E. Piccinini, R. W. Gregory, L. Kolbe, Changes in the Producer-Consumer Relationship - Towards Digital Transformation, Wirtschaftsinformatik Proceedings (2015). Access mode: https://www.researchgate.net/publication/277325460 Changes in the ProducerConsumer Relationship - Towards Digital Transformation

3. I. A. Krasyuk, M. V. Kolgan, Conditions and criteria for the implementation of integration in the chain of interaction between producer and consumer, taking into account digitalization, Actual issues of marketing development: experience, trends, innovations, 9 -20 (2021)

4. L. V. Vatlina, O. N. Moroz, Digital prospects of the consumer market and the service sector of Russia, Bulletin of the Siberian University of Consumer Cooperation, 1(35), 77-83 (2021)

5. E. G. Radygina, New opportunities for interaction with consumers of services in the conditions of digital transformation, Bulletin of the Academy of Knowledge, 1(36), 201-205 (2020)

6. I. V. Sergeev, State regulation of digital trade in the context of the development of integration processes in the economic sphere, Bulletin of the Russian Customs Academy, 4 (2019). Access mode: https://cyberleninka.ru/article/n/gosudarstvennoeregulirovanie-tsifrovoy-torgovli-v-usloviyah-razvitiya-integratsionnyh-protsessov-vekonomicheskoy-sfere

7. Official website of the Federal State Statistics Service: section "On industrial production in 2021" (2021). Access mode: https://gks.ru/bgd/regl/b21 01/Main.htm

8. Official website of the Federal State Statistics Service for the Khabarovsk Territory: section "On industrial production in 2021" (2021). Access mode: https://habstat.gks.ru/vrp hbr

9. Official website of the Ministry of Industry and Trade of Russia (2021). Access mode: https://minpromtorg.gov.ru/press centre/news/\#!minpromtorg_i_rosstandart_obnovili_perspektivnyy_plan_standartizacii _tehnologiy_industrii_40

10. Official website of the Federal State Statistics Service: section "Digital Economy of the Russian Federation" (2021). Access mode: http://www.gks.ru/free_doc/new_site/figure/anketa1-4.html

11. Official website "On personnel policy and technologies" (2021). Access mode: http://www.vivakadry.com/100.htm /

12. Innovative development of economic systems in the context of digitalization. Monograph (2021). Access mode: https://izd-mn.com/PDF/07MNNPM21.pdf

13. I. Sidorina, The Russian machine tool industry is preparing the Renaissance, Newspaper "Expert", 13 (2021). Access mode: https://expert.ru/2021/09/14/rossiyskomu-stankostroyeniyu-gotovyat-epokhuvozrozhdeniya/ 